\title{
Post-Operative Iron Carboxymaltose May Have an Effect on Haemoglobin Levels in Cardiothoracic Surgical Patients on the ICU - an Observational Pilot Study about Anaemia Treatment with Intravenous Iron
}

\author{
Frank Peters $^{a} \quad$ Maria Eveslage $^{b} \quad$ Inka Gallitz $^{a} \quad$ Carola Wempe $^{a} \quad$ Patrick Meybohm $^{c}$ \\ Hugo K. Van Aken ${ }^{a}$ Andrea U. Steinbicker ${ }^{a}$ \\ a Department of Anaesthesiology, Intensive Care and Pain Medicine, University Hospital Münster, University of Münster, Münster, Germany; \\ b Institute of Biostatistics and Clinical Research, University of Münster, Münster, Germany; \\ ${ }^{\mathrm{c}}$ Department of Anaesthesiology, Intensive Care Medicine and Pain Therapy, University Hospital Frankfurt, Frankfurt/M., Germany
}

\section{Keywords}

Intensive care unit - Anaemia · Ferric carboxymaltose . Blood transfusions

\begin{abstract}
Summary
Background: Post-operative anaemia is associated with increased morbidity and mortality. Positive effects of postoperative intravenous iron (IVI) after elective orthopaedic, abdominal and genitourinary surgery have been reported. The current observational trial investigated the prevalence of post-operative anaemia, the effect of IVI on haemoglobin levels, the use of blood transfusions and diagnoses related to infections. Methods: 1,265 patients on five ICUs of Münster University Hospital were screened for post-operative anaemia. On one ICU, patients were screened for iron deficiency and, if indicated, supplemented with $500 \mathrm{mg}$ of ferric carboxymaltose. Primary outcome measures were haemoglobin levels, C-reactive protein, white blood cell count, transfusion requirements, documented infection and antibiotic treatment. Results: Anaemia was prevalent in $86.2 \%$ of patients upon ICU admission. 429 patients were screened for iron deficiency anaemia. 95 patients were eligible, 35 were treated with IVI. An increase of +0.4 $\mathrm{g} / \mathrm{dl}$ in Hb levels 7 days after IVI compared to $-0.1 \mathrm{~g} / \mathrm{dl}$ in non-treated anaemic patients was observed. The number of RBC transfusions, ICD codes related to infections and infectious parameters were similar between groups. Conclusions: IVI treatment was safe and resulted in higher median $\mathrm{Hb}$ levels. Randomized controlled trials are required to support the hypotheses of this study.
\end{abstract}

(c) 2018 S. Karger GmbH, Freiburg

\section{Introduction}

There is a high level of evidence, that intravenous iron (IVI) is an effective treatment of pre-operative anaemia $[1,2]$. In cardiothoracic surgery, however, pre-operative treatment is often not feasible due to logistics or emergencies, while bleeding and major surgery leads to iron deficiency. Thus, post-operative anaemia treatment on the intensive care unit (ICU) has to be elucidated, but special circumstances are challenging: a) labile iron enhances oxidative stress, b) free iron and transferrin-bound iron are known to enhance infections [3], c) the bone marrow is suppressed by inflammatory cytokines, d) the bone marrow is less responsive to erythropoietin and e) major surgery can be followed by a systemic inflammatory reaction (SIRS). SIRS does not necessarily lead to specific infections (i.e. pneumonia or wound infections), but induces hepcidin, the main regulator of systemic iron homeostasis. Hepcidin degrades ferroportin, the iron exporter of the body, which impairs intestinal iron absorption and traps iron within body iron stores $[4,5]$. Iron-restricted erythropoiesis is frequent on the ICU and correlates with the need for RBC transfusions [6]. RBCs increase inflammation and have known, common side effects that may be caused by delivery of free and transferrin-bound iron [7]. Recent trials have shown increased haemoglobin (Hb) levels after the use of post-operative IVI in patients after elective major orthopaedic surgery as well as abdominal and genitourinary surgery [8] and in internal medicine and surgical ICU patients [9]. In patients undergoing cardiac surgery, however, the use of postoperative IVI has yet to be investigated.

In the present study, we determined the prevalence of post-operative anaemia in 1,265 patients on five ICUs of the Department of Anaesthesia, Intensive Care and Pain Medicine at Münster Uni-

\section{KARGER}

() 2018 S. Karger GmbH, Freiburg
Andrea U. Steinbicker, MD, MPH 
Fig. 1. Treatment of post-operative anaemia on the ICU. A According to the definition of the World Health Organization (WHO), post-operative $\mathrm{Hb}$ values in men were analysed upon admission to ICU into the categories non-anaemic $\mathrm{Hb} \geq 13 \mathrm{~g} / \mathrm{dl}$, mildly anaemic $\mathrm{Hb} 11.0-12.9 \mathrm{~g} / \mathrm{dl}$, moderately anaemic $\mathrm{Hb} 8.0-10.9 \mathrm{~g} / \mathrm{dl}$, and severely anaemic $\mathrm{Hb}$ $<8 \mathrm{~g} / \mathrm{dl}$. B Categorization of post-operative anaemia in women was performed as follows: non-anaemic $\mathrm{Hb} \geq 12 \mathrm{~g} / \mathrm{dl}$, mildlyanaemic $11.0-11.9 \mathrm{~g} / \mathrm{dl}$, moderately anaemic $\mathrm{Hb} 8.0-10.9 \mathrm{~g} / \mathrm{dl}$ and severely anaemic $\mathrm{Hb}<8 \mathrm{~g} / \mathrm{dl}$. C Of 429 patients admitted to the IV iron ICU, only 95 (22\%) presented no contraindications and were therefore eligible for IVI treatment. 35 of those 95 received IV iron and 60 were not treated due to different reasons such as lack of time, physician not experienced with IVI etc. A total of 262 patients (61\%) presented contraindications, in detail: $92 \mathrm{had}$ signs of infections during the first days after admission, 72 patients did not stay long enough on the ICU to assess and treat iron deficiency. D The boxplots show the median change of $\mathrm{Hb}$ levels between baseline at day of IVI substitution until day seven after substitution. Patients were

A
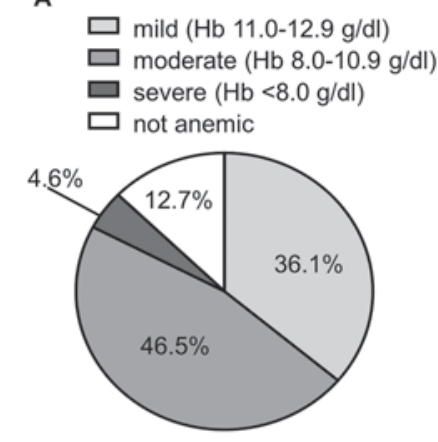

C
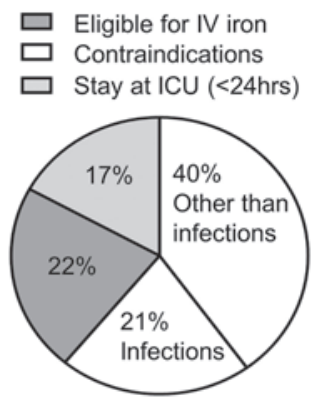

B
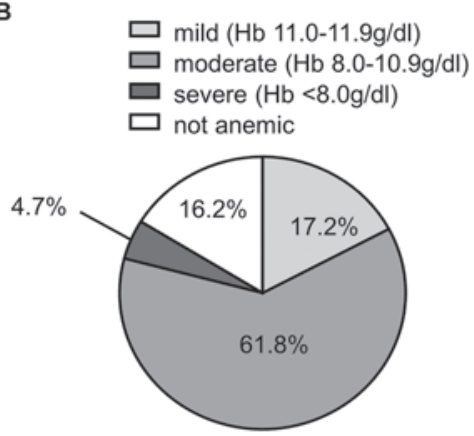

D

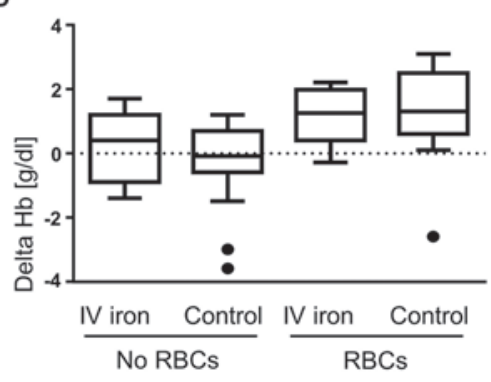
grouped according to the transfusion status. The two boxplots on the left (No RBCs) display the non-transfused subgroup. A small Hb increase of $0.4 \mathrm{~g} / \mathrm{dl}$ was observed in the IVI group, whereas the control group decreased by $-0.1 \mathrm{~g} / \mathrm{dl}$ ( $\mathrm{p}=0.34$, n.s.). The transfused subgroup is shown on the right side. No effect of IVI can be seen in this cohort, as transfusion of RBCs raised Hb levels by $1.3 \mathrm{~g} / \mathrm{dl}$ in both groups, the IVI and control group ( $\mathrm{p}=0.85$, n.s.).

versity Hospital, with the majority of patients undergoing cardiothoracic surgery. On one of the two cardiothoracic ICUs, post-operative iron-deficiency anaemia was treated with iron carboxymaltose. The aim was to determine the effect of IVI on Hb levels, the use of blood transfusions and diagnoses related to infections.

\section{Material and Methods}

A study on the implementation of patient blood management (PBM) and treatment of anaemia in four German University Hospitals was registered at clinicaltrial.gov NCT01820949. The present study was one part of the PBM implementation at Münster University Hospital. The results of the PBM implementation in four German University Hospitals were published in 2016 [10].

As the IVI substitution could not be started within the whole hospital at the same time, one ICU was given the pioneering task, and thus a comparison was possible. For post-operative anaemia treatment, the Ethical Committee was consulted prior to the observational pilot study at a single centre (Münster University Hospital) (Ethical Committee vote number 2013-217-b-S) and waived an informed patient's consent. Nevertheless, patients or their authorized representatives gave an informed consent on ferric carboxymaltose supplementation on the ICU.

\section{Data Collection}

From April 1, to December 31, 2014, 1,265 patients, who were admitted post-operatively or as an emergency case to one of the five peri-operative ICUs, were screened for anaemia $(\mathrm{Hb}<12$ and $/ 13 \mathrm{~g} / \mathrm{dl}$ for women and men respectively) and severe anaemia $\mathrm{Hb}<8 \mathrm{~g} / \mathrm{dl}$ ) (supplemental fig. 1, available at $h t t p: / /$ content.karger.com/ProdukteDB/produkte.asp?doi=481143). The iron status (serum iron levels, ferritin, transferrin, transferrin saturation) of anaemic patients was determined within $24 \mathrm{~h}$ upon arrival on the 'ICU 1'. Iron deficiency was defined as $\mathrm{Hb}$ levels below $12 \mathrm{~g} / \mathrm{dl}$ for women and below $13 \mathrm{~g} / \mathrm{dl}$ for men as well as transferrin saturation below $20 \%$ and ferritin levels below $400 \mu \mathrm{g} / \mathrm{l}$. Upon diagnosis of iron deficiency anaemia, contraindications were evaluated according to supplemental table 1 (available at http://content.karger.com/ ProdukteDB/produkte.asp?doi=481143). If indicated, $500 \mathrm{mg}$ of IV ferric carboxymaltose were administered [11].

On 'ICUs 2-5', patients were treated according to the standard procedure: anaemia was treated with RBC transfusions if required, the iron status was not regularly determined, and IVI was supplemented rarely.

With the implementation of PBM at Münster University Hospital, transfusions were indicated in accordance with the German guideline for transfusions [12]. Transfusion triggers were $\mathrm{Hb}$ levels between 6 and $8 \mathrm{~g} / \mathrm{dl}$. The transfusion trigger used on the ICUs at average in all patients was $7.1 \mathrm{~g} / \mathrm{dl} \mathrm{Hb}$.

$\mathrm{Hb}$ levels, C-reactive protein, white blood cells, number of RBCs, transfusion triggers, documented infection and antibiotic treatment were retrospectively analysed.

Patients (ICU 1 and 2) treated with IVI were matched 1:2 to patients without IVI treatment (see supplemental table 2, available at http://content.karger. com/ProdukteDB/produkte.asp?doi=481143).

These matched patients were patients from the cohort of the 60 patients, who were eligible, but not enrolled in the study and from eligible, but not treated controls from ICUs 2-5.

\section{Statistical Analysis}

Statistical analysis was performed using SPSS $22^{\circledR}$ for Windows (IBM Corporation, Somers, NY, USA) and SAS ${ }^{\circledR}$ software, version 9.4, for Windows (SAS Institute, Cary, NC, USA).

For more details, please see the additional 'Methods' section in the supplemental material (available at http://content.karger.com/ProdukteDB/produkte. asp?doi=481143).

\section{Results}

\section{Patients' Characteristics}

Of the 1,265 patients screened for anaemia upon admission to the ICU, $68.3 \%$ were male and $31.7 \%$ female. The mean age of pa- 
tients was $64.3 \pm 15.1$ years (see supplemental table 3 , available at http://content.karger.com/ProdukteDB/produkte.asp?doi=481143).

$64 \%$ of patients admitted to the ICU $(1+2)$ underwent cardiothoracic surgery, while the remaining had thoracic, orthopaedic, vascular, oral and maxillofacial surgery, neurosurgery and urology (supplemental fig. 2, available at http://content.karger.com/ProdukteDB/produkte.asp?doi=481143).

\section{Prevalence of Anaemia}

At admission, $86.2 \%$ of patients $(1,090 / 1,265)$ were anaemic ( $87.3 \%$ and $83.8 \%$ of men and women respectively) (fig. 1A, B). The mean $\mathrm{Hb}$ level was $10.7 \pm 1.7 \mathrm{~g} / \mathrm{dl}$ in all patients. $4.6 \%$ of men and $4.7 \%$ of women presented with severe anaemia, $46.5 \%$ of men and $61.8 \%$ of women were moderately anaemic, and mild anaemia was diagnosed in $36.1 \%$ of men and $17.2 \%$ of women. Only $12.7 \%$ of men and $16.2 \%$ of women had no anaemia.

\section{Iron Deficiency Anaemia and IVI Substitution}

On ICU 1, 429 patients were screened for iron deficiency anaemia and IVI substitution. $\mathrm{N}=262$ (61\%) presented with contraindications to ferric carboxymaltose supplementation (fig. 1C). About one-quarter $(n=92(21 \%))$ had an infection, $40 \%$ had other contraindications, and 72 patients (17\%) were not treated as they stayed less than $24 \mathrm{~h}$ on the ICU. Therefore, $\mathrm{n}=95$ patients ( $\mathrm{n}=64$ male, $\mathrm{n}=31$ female) had anaemia without contraindications for IVI supplementation. In order to substitute IV ferric carboxymaltose, the iron status had to be determined. In 35 of 95 patients, IV ferric carboxymaltose was given. The remaining 60 patients were not treated due to incomplete or missing iron status or other medical priorities of the physician on call. No adverse reaction was observed to IV ferric carboxymaltose. The iron status was within similar ranges in patients treated with IVI and in the non-IVI -treated matched pairs (supplemental table 5, available at $h t t p: / /$ content.karger.com/ProdukteDB/produkte.asp?doi=481143).

\section{Effect of IV Iron on Hb Levels and the Need for RBC}

\section{Transfusions}

All patients $(\mathrm{n}=61)$, who were still in hospital at day 7 presented a median increase of $0.4 \mathrm{~g} / \mathrm{dl} \mathrm{Hb}$ (IQR: -0.2 to 1.2 ). $\mathrm{N}=26$ patients treated with IV ferric carboxymaltose were matched to $\mathrm{n}$ $=52$ non-treated anaemic patients (fig. 1D). In the subgroup of patients without RBC transfusion, IVI was associated with a median $\mathrm{Hb}$ increase of $+0.4 \mathrm{~g} / \mathrm{dl}$ (IQR -0.9 to $1.2 \mathrm{~g} / \mathrm{dl}, \mathrm{n}=11$ ) versus $-0.1 \mathrm{~g} / \mathrm{dl}$ (IQR: -0.5 to $0.7, \mathrm{n}=29$ ) in the control group after 7 days.

After 14 days, patients without RBC transfusion showed an increase of their median $\mathrm{Hb}$ level by $0.6 \mathrm{~g} / \mathrm{dl}$ when treated with IVI ( $\mathrm{n}$ $=2$ ) compared to $0.5 \mathrm{~g} / \mathrm{dl}$ without IVI $(\mathrm{n}=4)$. In the IVI group, 0.5 $\pm 0.7 \mathrm{RBCs} /$ patient were transfused. Nine of 26 patients (35\%) received a transfusion (average $1.3 \mathrm{RBCs} /$ patient). In the control group, $0.6 \pm 0.9 \mathrm{RBCs} /$ patient were transfused, and 15 of $52 \mathrm{pa}-$ tients (29\%) received a transfusion (average $1.9 \mathrm{RBCs} /$ patient) (supplemental fig. 3, available at http://content.karger.com/ProdukteDB/produkte.asp?doi=481143). In the control group 93\% (14 of
15 patients) of the patients received a so-called 'doublet-transfusion', which means two RBCs transfused in a row. In the IVI group there were only 3 of 9 patients (33\%) with doublet transfusion. The remaining patients received one single $\mathrm{RBC}$ at a time.

\section{Effect of IVI Treatment on Clinically Apparent Infections}

As iron may enhance infections, the clinical records of the 78 patients (IVI treatment plus matched pairs) were analysed for documented infections. Between days 0 and 14 after IVI, 6 of 26 patients (23\%) suffered from infections,, whereas in the control group 14 of 52 patients $(27 \%)$ of the controls showed signs of infection (supplemental fig. 4 , available at $h t t p: / / c o n t e n t$.karger.com/ProdukteDB/ produkte.asp?doi=481143). The mean onset time of an infection was $5 \pm 3$ days after IVI in all 78 patients. The counts of white blood cells (WBCs) and C-reactive protein (CRP) did not indicate a difference between both groups (supplemental fig. 5, available at http://content.karger.com/ProdukteDB/produkte.asp?doi=481143).

\section{Discussion}

Post-operative anaemia treatment is a challenge. In this observational study, post-operative anaemia was present in $86.2 \%$ of 1,265 mainly cardiothoracic ICU patients. When checked for iron deficiency, about one-quarter of patients was eligible for treatment with IVI. Two-thirds (61\%) presented contraindications or stayed less than $24 \mathrm{~h}$ at the ICU, one-third of patients suffered from anaemia of chronic disease. Of the patients eligible for IVI, only onethird of patients received IVI. This result indicated that in ICUs physicians have to set other medical priorities and first have to apply life-saving treatments than to deal with iron deficiency.

Due to the retrospective, observational design, the current study has some limitations. The anaemia prevalence was determined on the five ICUs of the Department of Anaesthesia, Intensive Care and Pain Medicine of Münster University Hospital with their typical variety of patients. IVI treatment and major matching patients were both predominantly found in the ICU for cardiothoracic patients. A second point that has to be considered is the acute phase reaction after cardiothoracic surgery that led to the exclusion criteria prior to IVI administration as stated in the 'Material and Methods' section. As only a low number of patients could receive IVI, the results of the study have to be interpreted with caution and will have to be verified by a randomized controlled trial.

The prevalence of pre-operative anaemia was determined with $30 \%$ in patients undergoing various types of surgery in the European Outcome Studies (EUSOS) [13]. In 2011, Hung et al. [14] investigated the prevalence of anaemia in patients undergoing cardiac surgery in 2008 and 2009 in a single centre in the UK. They determined a very high anaemia prevalence of $54.4 \%$ (of 2,688 patients). The reason for the high prevalence had yet to be elucidated. In 2016, the first Cardiothoracic Anaesthetists national audit was performed in the UK. Data on anaemia and transfusion was analysed from 19,033 patients operated on in 12 cardiac surgical centres between 2010 and 2012 [15]. At average, the anaemia preva- 
lence was $31 \%$, but centre-specific prevalences varied from 23 to $45 \%$. Anaemia was associated with older patients, diabetes and surgical risk (Euro-SCORE). Patients with anaemia were twice as likely to die after cardiac surgery, and mortality was linked to severity of pre-operative anaemia and gender [15].

Major surgery, such as cardiothoracic or neurosurgery, may lead to a dysregulation of systemic iron homeostasis. We (data not published) and others [16] have measured serum hepcidin levels in some of these patients. Hepcidin induction increases after major surgery to values of $2,000-8,000 \mu \mathrm{g} / \mathrm{dl}$, while pre-operative values were around $480 \mu \mathrm{g} / \mathrm{dl}$. Hepcidin, in turn, binds to and degrades ferroportin, the sole iron absorption channel in vertebrates. As a consequence, iron cannot be absorbed in the intestine and remains trapped within iron storage sites such as hepatocytes or macrophages [4]. The days after surgery, hepcidin decreases again, and iron is available. Therefore, iron may be available and used for erythropoiesis and may explain the similar $\mathrm{Hb}$ increases of $0.6 \mathrm{~g} / \mathrm{dl}$ and $0.5 \mathrm{~g} / \mathrm{dl}$ after 14 days in the non-transfused cohort of patients treated either with or without IVI.

In this analysis, a difference of change in the $\mathrm{Hb}$ level of $0.5 \mathrm{~g} / \mathrm{dl}$ was observed in IVI treated compared to non-treated matched pairs within 7 days. This increase was not significant, most probably due to the low number of cases. The number of transfused RBCs was not different within the groups. When correctly applied, IVI was found safe and did not increase inflammatory parameters or diagnoses related to infections. These data are in line with the recently published results of the IRONMAN trial [9] reporting a difference of $0.7 \mathrm{~g} / \mathrm{dl}$ in $\mathrm{Hb}$ after 15-18 days. In an RCT including orthopaedic and general surgery patients, Khalafallah et. al. [8] observed a mean difference of $0.78 \mathrm{~g} / \mathrm{dl} \mathrm{Hb}$ with and without IV iron treatment after 4 weeks.

\section{Conclusion}

Further randomized controlled trials are necessary to clarify if cardiothoracic patients respond well to IV iron.

\section{Acknowledgements}

\section{Assistance with the Article: None.}

Financial Support and Sponsorship: AUS is supported by a DFG grant (STE1895-4/1). HVA and PM received an industrial grant for the implementation of Patient Blood Management.

Presentation: A presentations of preliminary data was given at the German Anaesthesia Society meeting in April 2015.

Authors' Contribution: FP collected data, performed the analysis and wrote the manuscript. ME and IG performed the analysis and wrote the manuscript. CW organized the Ethical Committee Correspondence, gave critical insights on study planning and wrote the manuscript, PM and HVA gave comments on the manuscript. AUS designed the study, analysed data and wrote the manuscript. All authors fulfil the four conditions of authorship to comply with ICMJE recommendations.

The authors thank Professor Kai Zacharowski and Dr. Dania Fischer of the Department of Anaesthesiology, Intensive Care and Pain Medicine at the University Hospital Frankfurt for the initiation of the trial to implement Patient Blood Management in four University Hospitals in Germany. The authors thank Professor Dr. P. Knüfermann, Gemeinschaftskrankenhaus Bonn, Department of Anaesthesiology, Intensive Care and Pain Medicine, Bonn, Germany for valuable scientific discussions on the use of IVI on the ICUs.

\section{Disclosure Statement}

HVA and PM received an industrial grant for the implementation of Patient Blood Management. The other authors declare to have no conflict of interest.

\section{References}

1 Rognoni C, Venturini S, Meregaglia M, Marmifero M, Tarricone R: Efficacy and safety of ferric carboxymaltose and other formulations in iron-deficient patients: a systematic review and network meta-analysis of randomised controlled trials. Clin Drug Invest 2016;36:177-194.

2 Peters F, Ellermann I, Steinbicker AU: Intravenous iron for treatment of anemia in the 3 perisurgical phases: a review and analysis of the current literature. Anesth Analg 2017; doi: 10.1213/ANE.0000000000002591.

3 Pieracci FM, Stovall RT, Jaouen B, Rodil M, Cappa A, Burlew CC, Holena DN, Maier R, Berry S, Jurkovich J, Moore EE: A Multicenter, Randomized clinical trial of IV Iron supplementation for anemia of traumatic critical illness. Crit Care Med 2014;42:2048-2057.

4 Steinbicker AU, Muckenthaler M: Out of balance systemic iron homeostasis in iron-related disorders. Nutrients 2013;5:3034-3061

5 Goodnough LT, Shander A, Spivak JL, Waters JH, Friedman AJ, Carson JL, Keating EM, Maddox T, Spence R: Detection, evaluation, and management of anemia in the elective surgical patient. Anesth Analg 2005;101:1858-1861.
6 Litton E, Xiao J, Allen CT, Ho KM: Iron-restricted erythropoiesis and risk of red blood cell transfusion in the intensive care unit: a prospective observational study. Anaesth Intensive Care 2015;43:612-616.

7 Rohde JM, Dimcheff DE, Blumberg N, Saint S, Langa KM, Kuhn L, Hickner A, Rogers MA: Health care-associated infection after red blood cell transfusion: a systematic review and meta-analysis. JAMA 2014;311: 1317-1326.

8 Khalafallah AA, Yan C, Al-Badri R, Robinson E, Kirkby BE, Ingram E, Gray Z, Khelgi V, Robertson IK, Kirkby BP: Intravenous ferric carboxymaltose versus standard care in the management of postoperative anaemia: a prospective, open-label, randomised controlled trial. Lancet Haematol 2016;3:e415-425.

9 IRONMAN Investigators, Litton E, Baker S, Erber WN, Farmer S, Ferrier J, French C, Gummer J, Hawkins D, Higgins A, Hofmann A, De Keulenaer B, McMorrow J, Olynyk JK, Richards T, Towler S, Trengove R, Webb S; Australian and New Zealand Intensive Care Society Clinical Trials Group: Intravenous iron or placebo for anaemia in intensive care: the IRONMAN multicentre randomized blinded trial : A randomized trial of IV iron in critical illness. Intensive Care Med 2016;42:1715-1722.
10 Meybohm P, Herrmann E, Steinbicker AU, Wittmann M, Gruenewald M, Fischer D, Baumgarten G, Renner J, Van Aken HK, Weber CF, Mueller MM, Geisen C, Rey J, Bon D, Hintereder G, Choorapoikayil S, Oldenburg J, Brockmann C, Geissler RG, Seifried E, Zacharowski K; PBM-study Collaborators: Patient blood management is associated with a substantial reduction of red blood cell utilization and safe for patient's outcome: a prospective, multicenter cohort study with a noninferiority design. Ann Surg 2016;264:203-211.

11 Package insert of 'Ferinject $50 \mathrm{mg}$ iron/ml', October 2013.

12 Vorstand der Bundesärztekammer auf Empfehlung des Wissenschaftlichen Beirats (eds): Querschnitts-Leitlinien (Bundesärztekammer) zur Therapie mit Blutkomponenten und Plasmaderivaten, 4. überarbeitete und aktualisierte Auflage. Cologne, Deutscher ÄrzteVerlag, 2014. www.bundesaerztekammer.de/fileadmin/ user_upload/downloads/QLL_Haemotherapie_2014. $p d f$ (last accessed December 27, 2017). 
13 Baron DM, Hochrieser H, Posch M, Metnitz B, Rhodes A, Moreno RP, Pearse RM, Metnitz P; ; European Surgical Outcomes Study (EuSOS) group for Trials Groups of European Society of Intensive Care Medicine; European Society of Anaesthesiology: Preoperative anaemia is associated with poor clinical outcome in non-cardiac surgery patients. Br J Anaesth 2014;113:416-423.
4 Hung M, Besser M, Sharples LD, Nair SK, Klein AA: The prevalence and association with transfusion, in tensive care unit stay and mortality of pre-operative anaemia in a cohort of cardiac surgery patients. Anaesthesia 2011;66:812-818.

15 Klein AA, Collier TJ, Brar MS, Evans C, Hallward G, Fletcher SN, Richards T; Association of Cardiothoracic Anaesthetists (ACTA): The incidence and importance of anaemia in patients undergoing cardiac surgery in the UK - the first Association of Cardiothoracic Anaesthetists national audit. Anaesthesia 2016;71:627-635.
16 Prowle JR, Calzavacca P, Licari E, Ligabo EV, Echeverri JE, Bagshaw SM, Haase-Fielitz A, Haase M, Ostland V, Noiri E, Westerman M, Devarajan P, Bellomo $\mathrm{R}$ : Combination of biomarkers for diagnosis of acute kidney injury after cardiopulmonary bypass. Ren Fail 2015;37:408-416. 